\title{
AN IMMIGRANT-FRIENDLY SCHOOL ACCORDING TO THE VIEWS OF STUDENTS, TEACHERS AND PRINCIPALS
}

\author{
RESEARCH ARTICLE
}

\begin{abstract}
Yusuf ALPAYDIN', Abdussamet AKTAŞ
1 Doç. Dr., Marmara University, Faculty of Education, yusuf.alpaydin@marmara.edu.tr, ORCID: 0000-0001-8263-8793.

2 Doctoral Student, Marmara University, Faculty of Education, asametaktas@gmail.com, ORCID: 0000-0002-8363-0053.
\end{abstract}

Geliş Tarihi: 28.06.2021 Kabul Tarihi: 26.10.2021 DOI: 10.37669 milliegitim.958429

\begin{abstract}
:
The aim of this research is to detect the problems that immigrant students experience during adaptation process; to demonstrate efforts made in the adaptation process to school and society and to provide a definition for immigrant-friendly school while also listing the qualities of this school. To achieve that objective, qualitative research method was adopted and via administering phenomenological approach, participants' views were analyzed in-depth. Semi-structured interview questions designed by researchers themselves were used as data collection tool. Population was determined through purposeful sampling method. The group consists of 8 immigrant students studying in high school grade during 2020-2021 academic year in Beykoz district of İstanbul city; 5 principals from high schools where immigrant students study and similarly 5 high school teachers having taught in immigrant students' lessons. Descriptive analysis method was administered to obtained data. Attained findings were examined within the framework of the theory of organizational socialization and interpreted by conducting immigrant-friendly city and immigrant-friendly hospital analogies. According to these findings during adaptation process immigrant students were exposed to academic, social, cultural and domestic(family-related) problems, and that immigrant-friendly schools put efforts in academic, social, cultural and parental support categories by harnessing varied organizational socialization tactics. Accordingly, immigrant-friendly school concept has been defined as; "an academic institution which-by making efforts needed- in academic, social, cultural support and parental support categories, expediting immigrant students' and their parents' adaptation to school and society". According to findings, qualities of an immigrant-friendly school are; enabling social participation, cultural interaction, facilitating access, financial assistance, family participation; offering academic support, psychological support; welcoming immigrant students and equality.
\end{abstract}

Keywords: Immigrant, Education, Friend, School 


\title{
ÖĞRENCI, ÖĞRETMEN VE OKUL MÜDÜRLERININ GÖRÜŞLERINE GÖRE GÖÇMEN DOSTU OKUL
}

\begin{abstract}
Öz: Bu araştırmanın amacı; göçmen öğrencilerin uyum sürecinde yaşadıkları sorunları tespit etmek, okula ve topluma uyumları sürecinde gerçekleştirilen çabaları ortaya koymak ve böylece göçmen dostu okul tanımını yaparak, bu okulun özelliklerini belirlemektir. Bu doğrultuda nitel araştırma yöntemi benimsenmiş olup, katılımcıların görüşleri fenomonolojik bir yaklaşımla derinlemesine analiz edilmiştir. Veri toplama aracı olarak, araştırmacılar tarafından hazırlanan yarı yapılandırılmış görüşme soruları kullanılmıştır. Çalışma grubu; amaçlı örnekleme yöntemiyle belirlenmiş olup, 2020-2021 eğitim öğretim yılında İstanbul ili Beykoz ilçesinde lise kademesinde öğrenim görmekte olan 8 göçmen öğrenci, göçmen öğrencisi bulunan lise kademesi okullardan 5 yönetici ve benzer şekilde lise kademesinde göçmen öğrencilerin derslerine girmiş 5 öğretmenden oluşmaktadır. Elde edilen verilerin incelenmesinde betimsel analiz yöntemi kullanılmıştır. Bulgular örgütsel sosyalizasyon teorisi çerçevesinde değerlendirilmiş, göçmen dostu şehir ve göçmen dostu hastane analojileri yapılarak yorumlanmıştır. Bulgulara göre göçmen öğrenciler uyum sürecinde akademik, sosyal, kültürel ve ailevi sorunlarla karşılaşmakta, göçmen dostu okullar ise çeşitli örgütsel sosyalizasyon taktiklerini kullanarak akademik, sosyal, kültürel destek ve ebeveyn desteği kategorilerinde çaba göstermektedirler. Bu doğrultuda göçmen dostu okul kavramı; "akademik, sosyal, kültürel destek ve ebeveyn desteği kategorilerinde gereken çabaları göstererek göçmen öğrencinin ve ebeveynin okula ve topluma uyumunu kolaylaştıran eğitim örgütleri" olarak tanımlanmıştır. Bulgulara göre göçmen dostu okulların özellikleri; sosyal katılım, kültürel etkileşim, erişimi kolaylaştırma, ekonomik destek, aile katılımı sağlama, akademik destek, psikolojik destek, göçmen öğrenciyi kabul, eşitlik şeklindedir.
\end{abstract}

Anahtar Kelimeler: Göçmen, Eğitim, Dost, Okul

\section{Introduction}

Since the dawn of history, migration has always existed in the lives of humankind. It can be claimed that migrations that were either voluntary or forced, temporary or permanent depending on underlying causes- have been a main source of interest in antique legends. Regardless of its causes or forms, migration has at all times existed as a tough process that resulted in a number of cultural, historical, psychological, economic and emotional interactions between individuals and communities.

Conceptually, migration is the act of moving from residential site to another one either individually or collectively and those who move (migrate) from one place to 
another are defined as immigrant (Turkish Language Society, 2020). Being forced to leave their homeland in pursuit of a better life, job and education opportunities, life security, due to famine, civil war and many other personal, societal, political, geographical, climatic and economic reasons, immigrants still face novel problems and challenges while leaving behind original problems. Fear of losing their job, viewing immigrants as potential criminals, reluctance to share national resources (Miller, 2020), concerns that life would be tougher, emotional and psychological feelings, xenophobic behaviors personally or politically among the members of host country (Betz \& Simpson, 2013) negatively affect the viewpoint of natives towards immigrants. In parallel with this viewpoint, immigrants experience discrimination, ostracization, physical, emotional, psychological and social violence; lack of access to vital services such as education, healthcare and security; financial troubles and housing problems in their newly-arrived society (Enoksen, 2019).

Negative attitude and behaviors exposed to immigrants are not limited with social life and adults only; but extend towards academic settings as well (Stevens, Boer, Titzmann, Cosma \& Walsh, 2020). Among the most pervasive problems at schools is negative reactions of parents in host country. Farre, Ortega and Tanaka (2018) claim that due to increased student population and student number per teacher, parents in host country avoid choosing schools with dense immigrant-student populating but rather favor private schools and they fear that quality of education would degrade in classrooms and schools in homeland. Jensen (2015) attributes these fears to; limited language skill and poor academic background of immigrant students, being have to share already-limited school resources, adverse behavioral and academic effects that grow among the students of the host country.

One of the most pervasive problems that immigrant students face at schools is discrimination. Discrimination, which initially takes place by segregating immigrant students in a different school or classroom (Yan, Wu, Liu \& Jiang, 2020), is exposed to immigrant students either by their peers in host state or even by teachers in certain instances (McCorkle, 2018). Other problems that immigrant students face at schools are; peer bullying, xenophobia, physical, social, emotional, psychological violence, language problem, cultural differences, fear and withdrawal (Omelchenko, 2019).

Such negative attitudes and behaviors faced at schools by immigrant students impede and even prevent adaptation to school and society; result in academic failure and trigger psychological and emotional problems. In here, it is detected that schools develop a number of solutions to stop problems faced by immigrant students and speed up their adaptation to school and society. For instance; partnering with various establishments (Koch, Gin \& Knutson, 2015), raising cultural awareness of school members (Schiff, 2008), conducting practices to integrate immigrant parents to education process (Albornoz, Cabrales and Hauk, 2018), accentuating the efforts to boost language learning (Bossavie, 2018), backing up immigrant students' academic background via 
supplementary works (Crosnoe \& Turley, 2011) are some of these efforts. Solutions administered in schools expedite immigrant students' adaptation to both school and society while also bolster their academic performance (Raol, 2020). In that case immigrant students' and parents' adaptation to school and society and minimizing potential negations will be proportional to the solutions applied by schools.

\section{Immigrant-friendly School}

In order to continue their life in a new community, immigrants take part in this new life by working in a job, shopping and benefiting from healthcare, education, transportation services etc.; therefore become a member of society. Within that context, building immigrant-friendly school model points at the necessity to form an immigrant-friendly society at first. Accordingly, the approach towards an immigrant-friendly school model will be branched from general to specific; from an immigrant-friendly society, immigrant-friendly city, immigrant-friendly organization to an immigrant-friendly school (Figure 1).

Figure 1. Immigrant-Friendly School From General To Specific

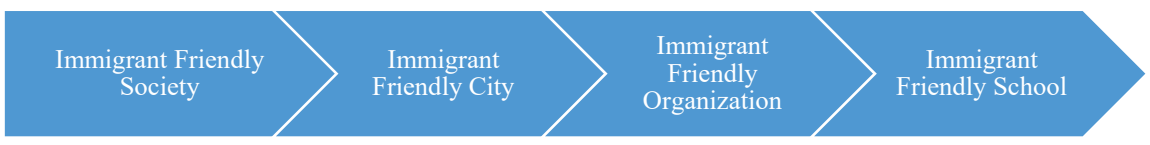

According to Figure 1, in order for an immigrant-friendly school to exist, in recognition of the problems faced by immigrants, it is essential to build a social structure that is named as immigrant-friendly society which is humanistic towards immigrants, which does not turn a blind eye on them and which adopts a philosophy of tolerance. An immigrant- friendly society provides equal rights with citizens of host state to immigrants in all dimensions of life, offers the same means and opportunities like the citizens of host state to immigrants, ensures safety of immigrants, develops immigrant-friendly practices and policies, enhance native citizens' educational and cultural level and as a result of these efforts, not many problems are witnessed in their acceptance by native society (Nukpezah, 2017). Besides, in such societies, religious and humanistic values are foregrounded to facilitate acceptance process of immigrants within the members of community (McDaniel, Nooriddin \& Shortle, 2011).

On the other hand as immigrant-friendly cities are examined it is witnessed that these places are valued as a safe haven by immigrants and these cities unconditionally welcome immigrants and are much experienced in adapting newcomers to urban life. According to Shepard (2016) qualities which help us define immigrant-friendly cities are such: Administrative leadership, Equal access, Civil participation, Affiliated organizations, Education, Economic development, Security. 
Such qualities steer generic policies of the city towards immigrants and allow the policies to be shaped as immigrant -friendly or anti-immigrant policies. Via immigrant-friendly policies immigrants are endowed with physical, emotional, social, and financial security; and they can also possess rights of equal access like the citizens of host state (Mitnik, Finnerty \& Vidal, 2008). Hostile policies on the other hand are the kind of policies that demotivate immigrants to live in the city and trigger locals to engage in violent acts towards immigrants and lead them to treat newcomers as potential criminals who would eventually increase crime ratios in their city (Hummel, 2015; Mitnik et al., 2008).

As we delve into the concept of immigrant-friendly organizations it is detected that researches foreground the kind of practices applied in hospitals. For instance; within the context of research conducted by Hudelson, Dao, Perneger and Paillard (2014) to build the culture of immigrant-friendly hospitals, practices listed below were conducted in selected hospitals as the sampling;

$\checkmark$ Assigning a reference nurse to provide information and support for hospital staff about the care of immigrant patients,

$\checkmark$ Rapid detection of patients in need of translator and meeting this need,

$\checkmark$ In cases when face-to-face access to translators is infeasible due to time and program restrictions, providing call on translation service,

$\checkmark$ Staff orientation days and demonstrating the nature of immigrant-friendly services to hospital staff,

$\checkmark$ Preparing and distributing informative brochures to spread healthcare awareness, acceptance and adoption among all staff,

$\checkmark$ To instill healthcare awareness among all staff, organizing musical entertainments, dinner parties, panels against anti-immigrant policies and racism in the hospital open to public; brochure distribution, video demos on local TV channels and websites; film demonstration to all staff and holding various cultural events.

In another research it was reported that in order to develop an immigrant-friendly approach in healthcare system and raise the awareness of healthcare staff, it is suggested to form several partnerships between healthcare employees and candidates in host country and healthcare establishments in the homelands of immigrants (Hickey, Gagnon \& Merry, 2010). Via such partnerships required information on the past experiences and healthcare background of immigrants could be gathered; hence immigrants could be better understood and a more functional communication could thus be established. 
Another research related to creating a hospital endowed with immigrant-friendly qualities was conducted by Jaeger, Kiss, Hossain and Zimmerman (2013). Findings of this research are deemed valuable for the immigrant-friendly school model; immigrant children have concerns and fears about the safety, immigrant children experience great cultural dilemma, various events is organized in order to ease immigrant children's adaptation, thus, immigrant children feels themselves more comfortable and safe, immigrant families ask to understand and be understood, employing a translator played quite a vital role in communicating with the immigrants without losing information.

Although immigrant-friendly organization practices are yet limited with hospitals, one other domain that needs such practices most is academic settings. Upon realizing the significance of education which was, for many long years, manipulated as a tool to assimilate immigrants or train unqualified laborer (Oktik \& Değer, 2013), in securing social order and immigrants' adaptation to society researches on education gained impetus. Through such studies it is detected that the first and foremost solution for helping immigrant students' and parents' adaptation to school and society could be offered by schools.

In here, immigrant-friendly schools that would be established on the basis of the theory of organizational socialization draw attention. Organizational socialization is a process in which various actions are performed to help the new member of organization be acquainted with the organization, adapt to the system and integrate to the organizational culture and in this process, both the organization and newcomer offer contribution (Malik \& Manroop, 2017). In this process the first stage is presocialization which is formed through the expectations of individual, meeting which indicates eagerness of the individual and organization in the adaptation to organization, change and gain stage which takes place if the process ends successfully and disassociation stage if it fails (Calik, 2003). A successfully socialized person is eager to stay in the organization and achieve high performance but if the socialization process ends in failure, the person encounters with negative physical, emotional, social, and psychological results and disassociates from the organization. In socialization process efforts that organizations make to swift new member's adaptation are executed via using certain tactics which can briefly be summarized such (Van Maanen \& Schein, 1979):

$\checkmark$ Collective-Personal; Socialization process that takes place as a group or in person.

$\checkmark$ Formal-Informal; Socialization process that takes place formally and planned or via informal methods.

$\checkmark$ Consecutive-Random; Socialization process that takes place either in a consecutive or random order until the target is attained.

$\checkmark$ Stabile-Unstable; Binding (or not )socialization process to a preset timetable. 
$\checkmark$ Series-Alternative; Receiving or not receiving support from an experienced member during socialization process.

$\checkmark$ Assignment-Discharge; Unconditionally accepting or rejecting the new member will all his/her traits during socialization process.

Organizational socialization process which indicates change, acculturation, transformation in feelings, thoughts, behaviors and attitudes which are necessary in organizational adaptation is impacted by a list of factors (Araza, Aslan \& Bulut, 2013). Bauer and Erdogan (2011) grouped these factors below three headings such as; personal traits, personal efforts and organizational efforts and explained them such; personal traits; assertiveness, interest in discovering the environment, rules and culture; personal efforts; willingness to learn what is expected from the person, asking questions and forming communication; organizational efforts; holding events and orientation programs to expedite socialization and applying organizational tactics during that process.

Immigrant-Friendly School Model which theoretically originates from organizational socialization approach accepts immigrant student as the individual and school as the organization. In that case; to help immigrant student manage socialization process brilliantly, problems experienced during the process, students' traits, students' efforts and school's efforts play a salient role. An immigrant student enters adaptation process under the effect of several factors and a number of problems and provided that efforts from both parties are sufficient, the process is then completed successfully. To that end, socialization process experienced in an immigrant-friendly school which observes theory of organizational socialization is as shown in Figure 2.

Figure 2. Socialization Process in Immigrant-friendly School within the Framework of Organizational Socialization Theory.

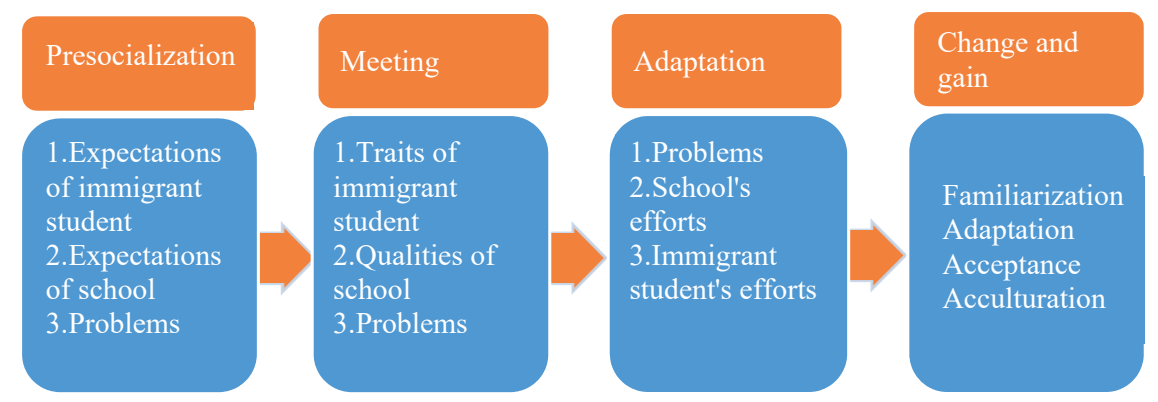

Resource: Adapted from Bauer \& Erdogan (2011), Calik (2003), Malik \& Manroop (2017).

In an immigrant-friendly school socialization process taking place within the framework of the theory of organizational socialization comprises of four stages which 
are; presocialization, meeting, adaptation, change and gain. Presocialization process relates to problems that an immigrant student copes with before starting school, expectations from school and school's expectations from immigrant students. Meeting process means that immigrant student can access school and refers to immigrant student's traits, school's qualities, emerging problems. During adaptation process it is possible to encounter new problems but school's and immigrant student's efforts are the anchor points. Change and gain, on the other hand, relates to the last stage in which socialization is completed successfully and problems are solved.

In an immigrant-friendly school, key point of socialization is immigrant student's efforts and school's efforts. Immigrant student's efforts can be defined as eagerness to form communication and partake in events and responding to school's efforts. School's efforts relate to events and activities that could minimize process related conflicts, offer problems to problems and expedite adaptation. At this point it is clear that school's efforts play a more vital role than student traits and student efforts since it offers solutions to problems. Hence, it is suggested to emphasize the efforts of model-school mentioned in researches.

Because of the new environment and new peers, contacting with a different language and culture, anxiety due to not being mature and a broken family environment at times; immigrant students are deeply in need of social, emotional and academic support. Schools which can offer these supports should firstly give a welcoming impression for immigrant students to help them feel safe in school environment. To create this environment Cardoza (2019) stated that hanging flags of different countries in corridors, posting informative texts written in native language in different places at school, enriching the library with publications written in native language, visiting immigrant students' homes are seemingly small but quite effective gestures in reality. Such efforts play a vital role in students' adaptation to society and school considering the hardships these students faced in their road to migration, assaults they faced, having lost some of their family members, being stranger in the country, culture and classroom, being the breadwinner in certain cases, being forced to work rather than attend school.

On the other hand these experiences also boost immigrant students' relentlessness, courage, persistence and problem-solving skills and increase their self-confidence. By implementing friendly practices, host school will expedite adaptation process and by revealing students' skills, experiences and cultural differences the school will gain more power (Lander, 2018). That being said, immigrant-friendly school practices will not only contribute to students' adaptation to school and society but will also allow the school and society to benefit from students' strengths.

With the practices immigrant-friendly schools conduct, they will offer psychosocial support to immigrant students and by actively conducting peer counseling, school will create a sense of safe environment and shorten integration process (European 
Commission, 2020; Konings, 2017). Another quality of immigrant-friendly schools in making the environment secure and create a sense of safe school is detecting students' private information, parental information and accommodation information by observing confidentiality (Koski, 2019). Thus, parents will be more eager to cooperate in sharing students' former experiences and feel at ease while sending their kids to school.

Leaving their home, family, friends, relatives and school behind after migration; students, in their new settlement, cope with language problem, ostracization, lack of family support and financial troubles. Solis (2016) reports that in order to solve problems, ensure adaptation and increase academic success schools should multiply finance resources, offer linguistic and academic support, employ immigrant teachers and conduct studies in boosting tolerance towards cultural differences, therefore make immigrant students feel valued. However discriminating immigrant students by the system or teachers prevents their healthy development and integration to society. Within that context, another practice expected from an immigrant-friendly school is to conduct trainings that focus on honing teachers' skills to work with immigrant students (Eren, 2019; OECD, 2015).

In their research reporting that schools hosting immigrant students are aware of the efforts they should make, Manzoni and Rolfe (2019) emphasized efforts made in Britain schools in order to solve immigrant students' problems and expedite adaptation to school and society as below;

$\checkmark$ Employing immigrant origin teacher or assistants at schools; These teachers knowing culture and language first-hand build a functional bridge between school and parents and be the source of knowledge and advice.

$\checkmark$ Assigning a delegate parent; Parents assigned by school convey school's expectations and education system of the country to immigrant families and by finding immigrant families in need, they organize relevant works.

$\checkmark$ Multilingual presentation of materials and employing translator; Materials that promote the school and society are printed in different languages and if needed, a translator is employed. In parent meetings and face-to-face interviews, translators play a role in raising immigrant families' interest to school.

$\checkmark$ Inclusion of immigrant parents to school life; events that cause no language barrier are held; In all cases communication and interaction is formed with immigrants, workshops, language courses, breakfast programs, fun events and various organizations are conducted.

$\checkmark$ Collecting data about immigrant family and student; Understanding the value of collecting data on students' academic background and home conditions, schools gather information on students and organize activities in light of gathered data. In the adaptation of newcomer students and families, immigrant 
families and students with the same background are included to the process, hence immigrant student and family can regard school as a safe environment.

$\checkmark$ Organizing extracurricular activities; Almost all schools organize extracurricular activities and events to offer social and academic support for immigrant students and build cooperation with public establishments and state foundations.

Another practice that would be exemplary of immigrant-friendly school model is practicing Sanctuary School Label and reward system. Sanctuary school means an embracing place for the student and families where immigrant students feel themselves safe and receive full acceptance (Education Authority, 2020). These schools train all of their shareholders about human rights, create a safe setting for immigrant students, promote cultural diversity, allow the immigrants' integration to society and raise empathy and intercultural awareness. By conducting related studies schools apply to a defined authority center and be awarded after evaluations (Schools of Sanctuary, 2020).

After all, it is known that immigrant students face language and culture friction, discrimination, verbal, emotional, physical and psychological pressure, financial lacks and adaptation problems at school. In this respect, the research draws attention to the problems experienced by immigrant students and parents, on the one hand, and on the other hand, the definition of immigrant-friendly school offers examples that can be applied in immigrant-friendly schools. Although there are some studies related to problems faced by immigrant students and solving adaptation problem, there has not yet been a study that presents immigrant-friendly school model within the framework of organizational socialization; thus this research is significant as it detects problems faced in socialization process, identifies efforts of immigrant student and immigrant-friendly school and demonstrates immigrant-friendly school model. In addition, this research is also deemed valuable as it examines the views of immigrant students, course teachers of immigrant students and principals of schools hosting immigrant students. It is expected that by the findings it showed this research would offer direct contribution to literature, school principals, teachers and indirect contribution to policy-makers by presenting a model of immigrant-friendly school. It is thought that this research will be a guide especially for school administrators, teachers and parents who experience immigrant student density and will contribute to minimizing the adaptation problems of immigrant students. Accordingly, within the framework of the theory of organizational socialization, objectives of this research are;

a) Spotting the problems faced by immigrant students in socialization process,

b) Spotting immigrant students' and schools' efforts made in socialization process,

c) By defining immigrant-friendly school, exhibiting its qualities so as to present an immigrant-friendly school model. 


\section{Methodology}

\section{Research Model}

The aim of this research is to detect problems that immigrant students experience during adaptation process, demonstrate efforts made in the adaptation process to school and society in order to provide a definition for immigrant-friendly school and identify the qualities of this school. To achieve that objective, qualitative research method was adopted and via administering phenomenological approach, participants' views were analyzed in-depth. Qualitative researches are geared at exploring and explaining the meaning people attribute to a social or human problem (Creswell, 1998). In phenomenology pattern a state, experience, event, perception or concept can be phenomena and an emerging state, experience and event is interpreted via participants' views (Groenewald, 2004). In phenomenological researches, the aim is to unveil examples, explanations and experiences that can allow us to collect detailed information on a phenomenon about which we are aware of but lack a deeper understanding (Y1ldırım \& Simsek, 2013).

\section{Population and Sampling}

Population of the research was selected via purposeful sampling method. Unlike selecting a random sampling, in purposeful sampling method, it is aimed to conduct an in-depth research by selecting situations and individuals that offer extensive data (Buyukozturk et al., 2018). Based on this fact, population consists of 8 immigrant students studying in a high school in Anatolian part of İstanbul, Beykoz district during 2020-2021 academic year and 5 principals and 5 teachers employed in that school. Sanders (1982) claims that in a phenomenological research lower limit of participants is 3 , Yildırım and Simsek (2016) reports that upper limit of participants is 10. In that case number of participants in this study is appropriate. Demographic information on participant students is as tabulated in Table 1.

Table 1. Information on Participant Students

\begin{tabular}{cccc}
\hline Nickname & Home country & Grade level & Educational background * \\
\hline S1 & Russia & 10 & 9 \\
\hline S2 & Moldova & 10 & 2 \\
\hline S3 & Turkmenistan & 10 & 1 \\
\hline S4 & Syria & 10 & 5 \\
\hline S5 & Uzbekistan & 10 & 2 \\
\hline S6 & Yemen & 11 & 3 \\
\hline S7 & Syria & 12 & 1 \\
\hline S8 & Afghanistan & 9 & 2 \\
\hline
\end{tabular}

${ }^{*}$ Not including current grade/number of years 
The research involved 8 students from 7 different nationalities and students' nicknames were coded as S1, S2. Although many of the students were tenth graders, it is detected that they have been in Turkish Education system for minimum 1, maximum 9 years. Demographic information on the interviewed teachers and school principals can be seen in Table 2 .

Table 2. Data on Participant Teachers and School principals

\begin{tabular}{ccc}
\hline Nickname & Gender & $\begin{array}{c}\text { Employment length with Immigrant } \\
\text { Students }^{*}\end{array}$ \\
\hline T1 & F & 2 \\
\hline T2 & F & 2 \\
\hline T3 & F & 3 \\
\hline T4 & F & 3 \\
\hline T5 & F & 4 \\
\hline P1 & M & 2 \\
\hline P2 & M & 5 \\
\hline P3 & M & 4 \\
\hline P4 & M & 15 \\
\hline P5 & M & 4 \\
\hline
\end{tabular}

*Year

In this study participant teachers are coded as T, school principals as P. 5 of the participant teachers are female, 5 school principals (all) are male and this is not a reflection of researcher's choice. That could be explained such; female gender teachers are the ones mostly in close contact with immigrant students or female teachers tend to be more eager to be a part of this research that focuses on immigrant students. The fact that all school principals in the research are male gender is that in proportion, men constitute nearly one hundred percent of all high school principals. It is seen that teachers have no long-term experience in teaching immigrant students and that school principals have longer time of work experience with immigrant students.

\section{Data Collection}

One of the qualitative research methods, interview technique and semi-structured interview form, was administered in the research. Semi-structured interview is an interview method that progresses in line with preset questions, avoids guiding the participant in line with responses, offering more flexibility for the participant than structured interview in terms of topic and responses and this method aims to attain in-depth information (Buyukozturk et al., 2018). 
During the preparation of the interview questions, first of all, a literature review was conducted on the research topic. Then, the questions to be used in the semi-structured interview were formed by consulting the opinions of two academicians who are experts in their fields. Before the interview participants were informed that the interview would last 45-60 minutes; their identity information would not be disclosed and obtained results would solely be used to serve the aims of this scientific research. Interviews were conducted and recorded by using tools for digital-communication technology.

\section{Data Analysis}

In the analysis of collected data descriptive analysis method was employed and in this method the aim is to organize, interpret obtained findings and come to a solution (Yıldırım \& Simsek, 2013). Recorded interviews were then transferred to Word processor with every detail recorded. Hence data were analyzed on Word processor. By employing straight-line coding method obtained data were analyzed one by one and solved by dividing below subthemes of; problems faced by immigrant students in adaptation process, immigrant students' efforts, immigrant-friendly school's efforts. During data analysis responses of participants for the same question were examined collectively and as obtained findings at the end of the analysis were transferred, participants' views were coded with nicknames: "S1, S2..,T1, T2.., P1, P2..".

Credibility, transferability, consistency and confirmability criteria are considered important to ensure the validity and reliability of qualitative research (Guba \& Lincoln, 1982). At the point of the credibility of the research; A semi-structured interview form was used as a data collection tool, the data obtained were evaluated by descriptive content analysis method, the analysis results were evaluated by experts, and the data obtained from the participants were compared with the data obtained by the literature review method. At the point of the transferability of the research, detailed information was given about all the stages of the research. At the point of the consistency of the research; The processes followed in the research were explained in detail, and the data obtained from the participant was also supported by the information obtained through the literature review method. In this way, comprehensive data on the subject have been obtained, and similar and different aspects of these data have been revealed. At the point of confirmability of the research, the data obtained in the research were presented clearly and the views of the participant were conveyed as they were.

\section{Findings}

At the end of the descriptive analysis on the obtained data from student, teacher and school principal views, findings were grouped below 1 theme and 3 subthemes. In the end, obtained subthemes from the analysis are as demonstrated in Figure 3. 
Figure 3. Themes detected in the research

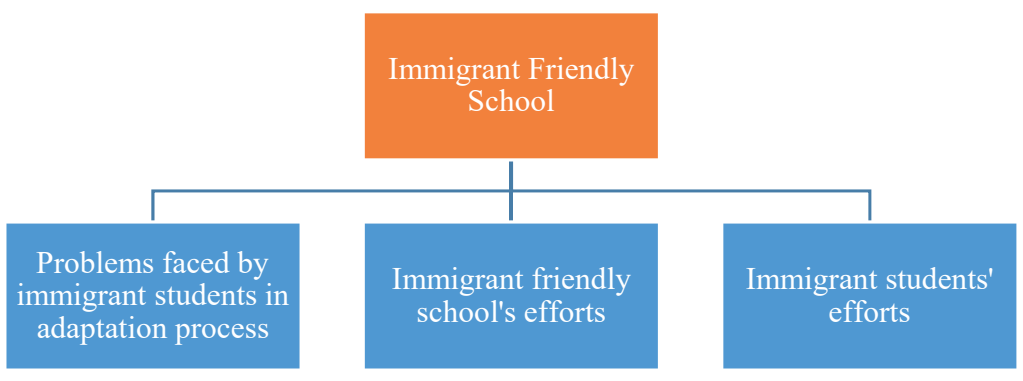

As shown in Figure 3 findings were grouped under three subthemes; problems faced by immigrant students in adaptation process, immigrant-friendly school's efforts and immigrant students' efforts after the descriptive analysis of data below immigrant-friendly school main theme. These subthemes which are based on the theory of organizational socialization were designed after the analysis of the views of immigrant students, school teachers and school principals and explained with their codes as can be seen below.

\section{Subtheme 1: Problems Faced By Immigrant Students In Adaptation Process}

Participants were asked; "What are the problems faced in adaptation process?" Codes that were created after analyzing obtained responses are as listed in Table 3. 
Table 3. Problems faced by Immigrant Students in Adaptation process

\begin{tabular}{|c|c|c|}
\hline Subtheme & Category & Code \\
\hline \multirow{4}{*}{$\begin{array}{l}\text { Problems Faced in } \\
\text { Adaptation Process }\end{array}$} & Academic & $\begin{array}{l}\text { - Language problem } \\
\text { - Academic Failure } \\
\text { - Having no Access to Education }\end{array}$ \\
\hline & Cultural & $\begin{array}{l}\text { - Differences between School Rules } \\
\text { - Differences between Society Rules }\end{array}$ \\
\hline & Social & $\begin{array}{l}\text { - Self-expression } \\
\text { - Lack of trust to the Environment } \\
\text { - Making Friends } \\
\text { - Peer- Inflicted Discrimination } \\
\text { - Teachers and School Staff- Inflicted } \\
\text { Discrimination } \\
\text { - Society- Inflicted Discrimination } \\
\text { - Worry, Fear and Withdrawal } \\
\text { - Physical, Social, Emotional , Psycho- } \\
\text { logical Intervention and Oppression }\end{array}$ \\
\hline & Domestic(family) & $\begin{array}{l}\text { - Financial Problems } \\
\text { - Many Numbers of Siblings } \\
\text { - Housing Problem } \\
\text { - Loss of a Parent } \\
\text { - Obligation to Work } \\
\text { - Parents' language problem }\end{array}$ \\
\hline
\end{tabular}

Obtained responses to the questions directed at participants so as to determine problems faced by immigrant students in adaptation process were coded and these codes were listed below four categories such as academic problems, cultural adaptation, social relations, domestic problems.

In adaptation process immigrant students listed language problem, academic failure and having no access to education and narrated the academic problems they faced. Participants' views in this category are such;

In my homeland I was very successful and I was even the best student at school but since I started this school here, I have faced academic failure for the first time in my life because of language problem...(S7).

For me, the biggest challenge was not knowing the language and not making friends...(S2).

These students experience many challenges but as we take a closer look at the problems, we realize that language is the main problem. Students are not able to converse or understand their surrounding, or socialize before learning the language and they fail to focus on lessons...(P3). 
An Immigrant-Friendly School According to the Views of Students, Teachers and Principals

With immigrant students having been here for long years there is not a language problem but with students who are still in adaptation process in their very first year it may be impossible to form communication at times...(T3).

At the end of data analysis it was detected that immigrant students underwent cultural adaptation problems that stemmed from the difference in school and society rules, values and beliefs. Participants' views in this category are such;

When I started school because of differences in school rules and my family life, I felt much confused...(S8).

In adaptation process immigrant students waver between their own culture, what they've learnt from their parents and our own culture. Quick reactions, hygiene habits, behavioral norms in society etc... (T3).

I can say that I had trouble in adopting school rules. In my homeland, we did not have to attend all lessons, we could skip some lessons if we wanted, we could go home early and also, lesson hours in our school were not the same as here...(S7).

In our culture jewelry has a special and unique place but here when I put on jewelry it was seen as breaking the rules...(S5).

Problems most widely experienced by immigrant students in adaptation process were "coded" below social problems category which came the first. That could be attributed to the fact that immigrant students want to interact with their surrounding, take part in peer groups and feel valued as an individual. These problems were seemingly attributed to the language problem faced by immigrant students and attitudes of peers in host state and school staff in host country towards immigrant students. In this category, participants' views are as reported below;

Until they learn to speak the language and complete adaptation process students choose to spend time alone, of course discrimination exposed by the peers, despise and similar behaviors are also responsible in making them feel that way...(P5).

No matter how well I knew Turkish language and could express myself clearly in that language, it was still quite worrying to settle in a totally strange country and strange school where I didn't know anyone at all and getting used to the environment, friends took quite a long time indeed(S1).

During the first days of school, everyone in class turned to me and laughed. Because of language problem I couldn't understand what was said. I felt terribly sorry and hoped to quit school as soon as possible. And if there was a planned event and no one else was willing to do it only after then would they ask me to do it...(S8). 
Many times I feel like invisible in class since they treat me like that, I think they don't want to include me in their group...(S7).

Shoulder punch, side-eyeing and mocking my eye form. I thought they wanted to make me feared and crash...(S5).

Because of different reasons some colleagues may be prejudiced and discriminatory towards immigrant students...(T1).

Crowded family, loss of a parent and obligation to work stand before us as domestic problems of immigrant students and it was detected that to cope with such problems immigrant students were forced to choose work rather than school to maintain family. Within that context participants' views are such;

Language was not the one and only problem of immigrant students. They had family problems as well. Some families don't want to send kids to school while other families exert violence and some others go through money issues...(T1).

One of my immigrant classmates had to go to work rather than school since he had no father and he was the sole breadwinner at home...(S4).

Since I have no mother I am in charge of my family members, my siblings' care and house chores, it was so hard for me to get dad's approval so that I could continue education...(S7).

Because of living in a foreign land and exposure to natives' discrimination these families believe that they will be treated the same at school too...(T3).

\section{Subtheme 2: Immigrant-Friendly School's Efforts}

Participants were asked; "In the face of problems related to adaptation process what are the efforts made by your school?". At the end of an analysis on obtained responses, designed codes are as displayed in Table 4. 
An Immigrant-Friendly School According to the Views of Students, Teachers and Principals

Table 4. Immigrant-Friendly School's Efforts During Adaptation Process

\begin{tabular}{|c|c|c|}
\hline Subtheme & Category & Code \\
\hline \multirow{4}{*}{$\begin{array}{l}\text { Immigrant-Friend- } \\
\text { ly School's Efforts }\end{array}$} & Academic Support & $\begin{array}{l}\text { - Voluntary teacher support in extracur- } \\
\text { ricular time } \\
\text { - Language course } \\
\text { - Inclusion of immigrant students in } \\
\text { projects that require taking responsi- } \\
\text { bility }\end{array}$ \\
\hline & Cultural Support & $\begin{array}{l}\text { - Informative texts printed in native lan- } \\
\text { guage Communication via translator } \\
\text { teacher } \\
\text { - Promoting the region } \\
\text { - Briefing on school rules and host } \\
\text { society }\end{array}$ \\
\hline & Social Support & $\begin{array}{l}\text { - Weekly meeting and inclusion events, } \\
\text { - Peer support } \\
\text { - "Value" based education for host } \\
\text { students Psychological support } \\
\text { - Events to raise awareness on the } \\
\text { presence of other immigrant students } \\
\text { at school } \\
\text { - Sports events } \\
\text { - Inclusive -education trainings for } \\
\text { teachers }\end{array}$ \\
\hline & Parental Support & $\begin{array}{l}\text { - Financial Support } \\
\text { - Psychological Support } \\
\text { - Language course } \\
\text { - Cooperation with state establishments } \\
\text { and NGOs } \\
\text { - Delegate parent } \\
\text { - House visits }\end{array}$ \\
\hline
\end{tabular}

According to socialization theory, adaptation problems are quite natural and in overcoming such problems corporate efforts play a vital role. To that end, obtained responses to the questions asked to participants in order to detect school's efforts in solving the problems faced by immigrant students in adaptation process were coded and these codes were listed below four categories such as; academic support, cultural support, social support, parental support.

In the face of academic problems faced by immigrant students it was seen that schools implemented solutions such as language course, voluntary teacher support and assigning academic responsibility to immigrant students. Participants' views below academic support category which is detected to have direct contribution to elevate immigrant students' academic success are as below listed; 
Outside of class hours, we offer language courses for immigrant students because a student who improves language starts to be more successful in other domains...(P3).

Because I am not very good at language yet, there are some topics I cannot understand in lessons. At break time my teachers assisted me by explaining them to me again... (S3).

I assigned these students to promote their own country in a national project and they were very successful. Immigrant students felt more confident in academic topics, our own students' attitude towards them changed and they started to respect and treat them in courtesy. I could never imagine that would be so helpful...(P2).

It was detected that by preparing texts written in immigrant students' native language, schools practiced cultural support by presenting school rules, region, host society and employing immigrant teacher or translator teacher. These efforts played a vital role in facilitating immigrant students' cultural adaptation and forming healthy communication with students and it was also witnessed that presence of a teacher speaking their native language made immigrant students feel most comfortable. In that sense, reported views of participants are such;

Until the time students learnt Turkish, we communicated with them through teachers who could speak students' native language. We introduced our school to them and paid publicity visits to school region and district...(P3).

We organized events and projects that allowed immigrant students to learn other cultures aside from ours. Instead of promoting our own culture only, exchanging information about other cultures speed up their adaptation to others... (P2).

On school walls there were notifications, rules, directives on certain parts of the school and they were written in my own language. Also as I was enrolling in school, they gave me informative texts in my native language... (S6).

In certain times, school bell is played in their mother tongue. We should let them feel that we are aware of their presence and we appreciate their participation...(T5).

In order to offer solutions to social problems category which represents the group in which immigrant students have greater problems in adaptation process, it was detected that schools organized; meeting events, gaining peer support, value-based trainings for host students, inclusive-education trainings for teachers, sports activities, psychological support and activities to achieve interaction with immigrant students. It is seen that schools' efforts mostly focus on social support. That could be related to the idea that by preventing exposure of immigrant students to discrimination, ost- 
racization, physical, social, emotional, psychological interventions only then helping them to complete their adaptation process as quickly and successfully as can be viable. Participants' views from this category named as social support are such;

On specific days every week, they organized chat room events after school. Immigrant students were invited and other students could also participate if they wanted. Thanks to these rooms, our affection for classmates as well as teachers and also school has climbed...(S6).

In school football tournament they included me to the team. Soon after I became a forward player in class...(S4).

Depending on the season and conditions we hold events in the school yard or make trips to different places...(P1).

My classmates were really interested in me. On my first day, they asked me questions about my nationality, name etc. after learning that I was a foreigner. They shared with me course notes and explained to me the topics I couldn't understand well in class...(S3).

Students and teachers can really be mean at times. We organized informative meetings for teachers on immigrant students. By cooperating with some NGOs and universities, we offered our teachers inclusive-education trainings...(P3).

Counselor teacher in our school is both quite accomplished and active in matters of psychological support. We ask for her support while still undergoing adaptation process...(T3).

Another problem experienced by immigrant students is domestic problems in their family. It was observed that due to financial burden, being forced to be the mom or dad at home due to loss of a parent or accommodation-related problems; some of the immigrant students could no longer continue school. In that sense it was detected in this study that for immigrant parents schools provided financial assistance, psychological support and language support; formed cooperation with several establishments; conducted house visits and selected delegate parent and all these efforts play a salient role in the inclusion of immigrant parents to education while helping them feel that school is a safe environment which can be trusted. Also it was monitored that practicing delegate parent model boosted communication with immigrant families. Participants' views below this category named as Parental support are as reported below;

We paid visits to these students' homes. We informed Turkish parents about immigrant families and motivated them to visit immigrant families at home to spark a sense of comfort and trust...(T3).

For a while, we offered financial assistance to immigrant families and next, we helped a student's dad get a job...(T2). 
My teacher found my dad a job and started to pay the rent of our home. Dad adopted a new perspective to school then and no longer had worries. Thanks to that, both me and my sibling can now continue education...(S3).

By cooperating with governmental and nongovernmental organizations we offered psychological support and financial assistance for families. Besides, we delegated an immigrant mother who could speak Turkish better than other moms to communicate with immigrant families and thanks to this delegate mom, we managed to reach and contact immigrant parents, sent our donations easily, included these families to education and helped them feel at peace...(P1).

As we were aware of the language problem of families, we offered language courses for these families...(P3).

When I started school first, they took me and my family to a healthcare institute where we got physical examination. Throughout the period we were there, they said we were more than welcome to use all services freely... (S2).

\section{Subtheme 3: Immigrant Students' Efforts}

Immigrant students were asked the question; "In order to speed up adaptation process, what are the efforts you make?". Codes that were formed as a result of the analysis on obtained responses can be seen in Table 5 .

Table 5. Immigrant Students' Efforts in Adaptation Process

\begin{tabular}{|c|c|c|}
\hline Subtheme & Category & Code \\
\hline \multirow{4}{*}{$\begin{array}{l}\text { Immigrant Students' } \\
\text { Efforts }\end{array}$} & Academic & $\begin{array}{l}\text { - Asking for support from teachers } \\
\text { - Peer communication to boost language } \\
\text { development } \\
\text { - Active participation in extracurricular } \\
\text { supplementary practices }\end{array}$ \\
\hline & Cultural & $\begin{array}{l}\text { - Communication with teachers and } \\
\text { school principal } \\
\text { - Willingness to adapt to cultural varian- } \\
\text { ces of the host school and society }\end{array}$ \\
\hline & Social & $\begin{array}{l}\text { - Active participation in organized events } \\
\text { and activities } \\
\text { - Initiating conversation with native peers } \\
\text { /responding positively to an initiated } \\
\text { talk } \\
\text { - Initiating conversation with other im- } \\
\text { migrant students }\end{array}$ \\
\hline & Domestic & $\begin{array}{l}\text { - Teaching Turkish language to parents } \\
\text { - Playing an active role in parent-school } \\
\text { communication }\end{array}$ \\
\hline
\end{tabular}


Socialization theory asserts that adaptation process can attain success through mutual efforts of both parties. Within that context it was aimed to detect the efforts made by immigrant students having completed adaptation process with success. Obtained responses in the conducted interviews were coded which were categorized below four titles as; academic effort, cultural effort, social effort, domestic effort.

Responses of immigrant students who stated that they were eager to learn Turkish and adapt to lessons with no delay can be defined as academic efforts in adaptation process. Participants' views in this category are as below;

To learn the language of my host nation, I was trying to converse with friends all the time and soon after I started to be understood by listeners...(S8).

During lesson break, I was asking about clarification to course teachers on the unclear topics for me...(S3).

Immigrant students reported their willingness and motivation to adapt to school and society, Turkish culture, school and society rules better. Participants' views in this category, which is named as cultural effort, are as below listed;

I participated in meeting events and in such occasions I had a chance to introduce my own culture and also to learn more about Turkish culture...(S6).

Immigrant students stated that they put efforts to make friends, mingle with peers, be a group member and expedite adaptation process. Participants' views in this category named as immigrant students' social effort are as shown below;

I realized that I had the similar music taste with two friends sitting near my chair. That gave me encouragement and made it easier for us to become friends...(S3).

There was another immigrant student in class and it helped me feel more confident. I was introduced to everyone during the meeting events held in our classroom. One week later there was class presidency election and I was one of the candidates...(S5).

Helping immigrant families to feel themselves secure, trusting to school, supporting their kids' education play a significant role in ensuring students' academic, cultural and social adaptation. Immigrant students have undertaken greater responsibility to motivate their families learn the language, adapt quickly to society and participate more to trainings so that families could adapt to society better. Participants' views below this category named as Domestic effort can be seen below;

My family also undergoes the same language problem like me and I try to teach them the language to the best of my knowledge...(S4).

When my parents need to talk to teachers or school principal, I try to translate as much as I can...(S7). 


\section{Conclusion and Discussion}

The aim of this research is to detect problems faced by immigrant students in school adaptation process and efforts made by immigrant students and schools to ensure adaptation while also listing the qualities required by defining the nature of an immigrant-friendly school. Within that scope the topic was examined within the framework of the theory of organizational socialization and analogies were drawn regarding to an immigrant-friendly society, city and hospital. In addition interviews were held to collect research findings among a sampling composed of eight immigrant students from different nationalities, five teachers and five school principals.

In accordance with research findings, definition of an immigrant-friendly school can be outlined such; "An academic establishment putting in effort to expedite successful adaptation of immigrant students to school and society and solve the problems experienced in adaptation process." In a school with immigrant-friendly nature there is academic, social, cultural and domestic support given to immigrant students to help them adapt to school and society; hence there is a minimum level of adaptation problems among immigrant students. In that sense by referring to research findings, qualities of an immigrant-friendly school were specified and displayed as seen in Figure 4.

Figure 4. Qualities of an Immigrant-Friendly School

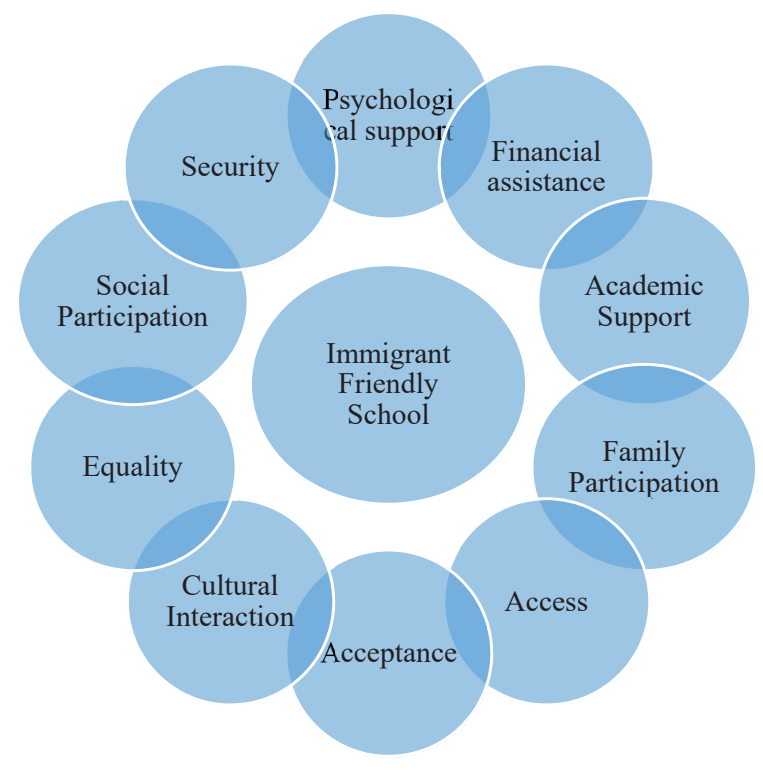


An Immigrant-Friendly School According to the Views of Students, Teachers and Principals

As seen in Figure 4 qualities of an immigrant-friendly school can be outlined as below;

$\checkmark$ Security; Physical, social, emotional and psychological security of immigrant students is secured and these students feel themselves safe at school.

$\checkmark$ Social Participation; Required opportunities and events to help socialize immigrant students are diversified.

$\checkmark$ Equality; Without discrimination immigrant students are all provided with the same means for equal access to every process and activity held at school.

$\checkmark$ Cultural Interaction; In order to expedite cultural interaction between host students and immigrant students and allow immigrant students' adaptation to host culture, a myriad of events are organized.

$\checkmark$ Acceptance; With all the traits and features they possess, immigrant students are unconditionally accepted by host students and school personnel and by exercising a culture of tolerance, they are integrated to peer groups, classroom setting and school environment.

$\checkmark$ Access; Efforts are made to solve the problems that block immigrant students' access to education.

$\checkmark$ Financial assistance; Financial assistance is provided to immigrant students and families.

$\checkmark$ Family Participation; Efforts are made to hold activities which involve parents to ensure that immigrant families communicate more with the teachers and parents in host country and to render support for students' academic, social and cultural adaptation.

$\checkmark$ Academic Support; In order to help immigrant students learn the language and boost academic success, extracurricular activities are planned.

$\checkmark$ Psychological Support; Offering practices that render psychological support for immigrant students and parents.

Findings have demonstrated that in the process of school adaptation, immigrant students experience language and culture difference, academic failure, difficulty in social relations, financial troubles, ostracization, loss of a parent, obligation to be the breadwinner at home, housing problems which are grouped below the categories of academic, cultural, social and domestic. In literature same problems have also been reported by other researchers (Albornoz et al., 2018; Bossavie, 2018; Farre et al., 2018; $\mathrm{Hu}$ and $\mathrm{Wu}, 2020$; Jensen, 2015; Schiff, 2008). It is quite normal that problems are expected for any individual when entering a foreign setting of which language and cultu- 
re is enigma. Theory of organizational socialization mandates that to overcome these problems, both the school and students are obliged to make efforts. Findings show that during socialization process schools mostly prefer socialization tactics listed as personal, informal and random tactics. That being said, it can be argued that in adaptation process schools opt for personal and random efforts rather than implementing planned, systematic and group-based efforts. As a result it is witnessed that immigrant students' adaptation to school and society is delayed.

According to research findings, in order to complete adaptation process in success and offer solutions to problems seen in adaptation process, schools put in efforts within the categories of academic, cultural, social and parental support. Provided services below these categories are; language course, extracurricular academic support, printed materials in native language, employing a translator teacher, meeting events, sports activities, psychological support, peer support, trainings for the host members of school, financial assistance for the parents etc. and these efforts are reported to be identical with researches in literature (Cardoza, 2019; Konings, 2017; Lander, 2018; Manzoni \& Rolfe, 2019). It has been observed that through these efforts immigrant students' academic success and parents' involvement with education climbed whereas immigrant family' problems in adaptation to society went down.

To ensure that organizational socialization is completed in success, there is need for both organizational efforts and personal efforts. In that context efforts made by immigrant students in their adaptation process were examined. Findings were examined below four categories as academic effort, cultural effort, social effort and domestic effort. Accordingly, in and outside of class hours immigrant students communicate with teachers and school principals and feel eager to partake in organized events, act courageously in interacting with native peers and other immigrant students and play an active role in teaching the language to their parents and asking them to participate in trainings. As exhibited by these findings, immigrant students who put sufficient efforts in adaptation process are much quicker in adapting to the school and society. This research finding is congruent with the theory of organizational socialization.

As efforts of school and immigrant students were analyzed together, it was seen that these efforts mostly accumulated in academic and social category. That finding can be related to the assumption that once problems in these two categories are solved, problems in other categories could automatically be solved. Indeed it was observed that immigrant students mostly repeated their language problem and exclusion from peer groups and paid more heeds to academic and social problems ongoing. Therefore, witnessing that both the school and students put more efforts in academic and social category is on the same line with existing problems.

Findings demonstrate that immigrant students hold expectations from schools to make greater efforts. Having felt valuable though these efforts, students also recognize 
the fact that these efforts work well in expediting their adaptation to school. Within that context the most noteworthy finding of the research is that interviewed immigrant students demand to get in touch with other immigrant students at school and ask the school management to enable their interaction with other immigrant peers. Thanks to these practices, immigrant students feel more relaxed and confident. That sense of comfort could be that the moment immigrant students realize that there are other people undergoing the same experiences with them in the same environment and communicate with these students, they would solve problems more quickly and confide their troubles to these students who, they believed, could understand them much better than others.

School efforts obtained from conducted interviews and literature review play a vital role in being an immigrant-friendly school. Accordingly, to exemplify the efforts that an immigrant-friendly school should make, obtained findings have been provided in Table 6. 
Table 6. Examples of Academic, Cultural, Social and Domestic Support at Immigrant Friendly Schools

\begin{tabular}{|c|c|c|c|}
\hline Academic & Cultural & Social & Domestic \\
\hline $\begin{array}{ll}\text { - Including } \\
\text { in projects } \\
\text { that require } \\
\text { assuming } \\
\text { responsibility } \\
\text { - Printing course } \\
\text { materials in } \\
\text { native langu- } \\
\text { age } \\
\text { Distributing } \\
\text { immigrant } \\
\text { students in } \\
\text { equal numbers } \\
\text { to classrooms }\end{array}$ & $\begin{array}{l}\text { - Preparing } \\
\text { promotional } \\
\text { materials in na- } \\
\text { tive- language } \\
\text { that introduce } \\
\text { school and } \\
\text { school rules and } \\
\text { host society } \\
\text { Posting infor- } \\
\text { mative texts and } \\
\text { statements in } \\
\text { native langua- } \\
\text { ge to different } \\
\text { areas at school }\end{array}$ & $\begin{array}{ll}\text { Employing trans- } \\
\text { lator teacher } \\
\text { Conducting pe- } \\
\text { riodical, planned } \\
\text { and systematic } \\
\text { meetings } \\
\text { Holding events } \\
\text { to facilitate inte- } \\
\text { raction among } \\
\text { immigrant stu- } \\
\text { dents themselves } \\
\text { Offering psycho- } \\
\text { social support } \\
\text { via school coun- } \\
\text { selor }\end{array}$ & $\begin{array}{l}\text { - Holding perio- } \\
\text { dical events that } \\
\text { enable all parents } \\
\text { in a classroom/ } \\
\text { school form } \\
\text { interaction and } \\
\text { communication; } \\
\text { breakfast prog- } \\
\text { rams etc. } \\
\text { Organizing hu- } \\
\text { manistic-values } \\
\text { based trainings } \\
\text { for parents in } \\
\text { host country } \\
\text { Opening lan- } \\
\text { guage courses } \\
\text { and vocational } \\
\text { courses }\end{array}$ \\
\hline 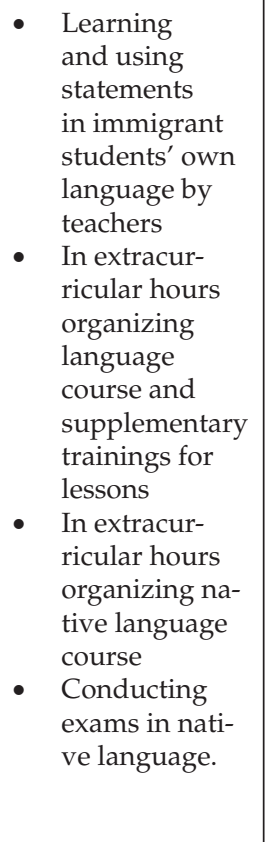 & $\begin{array}{l}\text { - Providing books } \\
\text { in native lan- } \\
\text { guage in school } \\
\text { library } \\
\text { Trainings and } \\
\text { cultural awa- } \\
\text { reness raising } \\
\text { events for host } \\
\text { members at } \\
\text { school } \\
\text { Holding pro- } \\
\text { motional events } \\
\text { for the members } \\
\text { of host society } \\
\text { to introduce } \\
\text { immigrant stu- } \\
\text { dents' language } \\
\text { and culture } \\
\text { Introducing } \\
\text { school region } \\
\text { via physical } \\
\text { trips etc. } \\
\text { Employing } \\
\text { immigrant } \\
\text { teachers. }\end{array}$ & $\begin{array}{l}\text { Organizing hu- } \\
\text { manistic-values } \\
\text { based activities } \\
\text { and trainings for } \\
\text { students in host } \\
\text { society } \\
\text { Organizing } \\
\text { sports activities, } \\
\text { trips, festivals in } \\
\text { which immigrant } \\
\text { students can take } \\
\text { an active role } \\
\text { Including immig- } \\
\text { rant students to } \\
\text { extracurricular } \\
\text { club activities. }\end{array}$ & $\begin{array}{l}\text { Financial support } \\
\text { through their } \\
\text { own budget or } \\
\text { benefactors, } \\
\text { NGOs } \\
\text { - Giving psycho- } \\
\text { social support } \\
\text { through coope- } \\
\text { rating with state } \\
\text { foundations and } \\
\text { NGOs, } \\
\text { By cooperating } \\
\text { with health- } \\
\text { care institutes } \\
\text { providing access } \\
\text { to healthcare } \\
\text { services } \\
\text { House visits } \\
\text { Appointing } \\
\text { delegate parents } \\
\text { to set the bridge } \\
\text { with immigrant } \\
\text { parents }\end{array}$ \\
\hline
\end{tabular}


Another finding of the research presents that school principals and teachers gave their approval to undergo immigrant-friendly school audits and certification process on a voluntary basis by following preset criteria. Yet, in addition to certification, participants suggested getting financial aids so that they would hold greater means of activities for immigrant students at schools. This finding of the research can be interpreted such; a mandatory immigrant-friendly school certification process would result in unforeseen effects. In addition it is realized that there is need for financial support so as to enrich adaptation efforts of immigrant-friendly schools.

In conclusion, as we analyze the increasing number of immigrants each day and problems faced by immigrant students at schools, it becomes more vital to prioritize the role of immigrant-friendly schools in adaptation process to school and society. Immigrant-friendly schools symbolize academic settings where immigrant students feel themselves safe like home; where immigrant families are treated as a whole and solutions are offered to their problems and in which immigrant students are supported in terms of academic, cultural, social and domestic aspects. Through their efforts immigrant-friendly schools can allow immigrant students and parent to be valued and protected at school and society and by motivating them to exhibit their true potential, these schools will let them offer contribution to community, be joyful and unite with host society. From this point of view it can be suggested to school principals and teachers to acknowledge the significance of efforts that immigrant -friendly schools would make in socialization process; thus make the required efforts to achieve smooth adaptation of immigrant students to society and school. By paying heeds to increasingly-growing mobility of immigrants globewide, policy-makers should value the role of immigrant-friendly schools and implement actions to evaluate the programs immigrant-friendly schools for certification process.

\section{References}

Albornoz, F., Cabrales, A. \& Hauk, E. (2018). Immigration and the school system. Econ Theory, 65, 855-890. https://doi.org/10.1007/s00199-017-1041-4

Araza, A., Aslan, G. \& Bulut, Ç. (2013). Organızatıonal socialızatıon: a literature review. Journal of Yasar University, 8(32), 5556-5582.

Arslangilay, A. S. (2018). The reflection of immigration on school culture: a qualitative study. International Journal of Instruction, 11(2), 585-602. https:/ / doi.org/10.12973/iji.2018.11240a

Bauer, T. N. \& Erdogan, B. (2011). Organızational socialization: The effective onboarding of new employees. In. APA Handbook of I/O Psychology, Volume III Chapter: 2. S. Zedeck., A. Aguinis., W. Cascio., M. Gelfand., K. Leung., S. Parker ve J. Zhou.

Betz, W. \& Simpson, N. (2013). The effects of international migration on the well-being of native populations in Europe. IZA Discussion Paper No. 7368. Retrieved October 1, 2020 from http://ftp.iza.org/dp7368.pdf 
Bossavie, L. (2018). The effect of immigration on natives' school achievement. The Journal of Human Resources. https://doi.org/10.3368/jhr.55.3.1017-9151R2

Buyukozturk, Ş., Çakmak, E. K., Akgün, Ö. E., Karadeniz, Ş. \& Demirel, F. (2018). Scientific Research Methods. Pegem Akademi.

Calik, T. (2003). Adaptation of employees to the organization (Organizational socialization). Turkish Journal of Educational Sciences, 1(2), 1-17.

Cardoza, K. (2019). How schools are responding to migrant children? Education Week. Retrieved October 1, 2020 from https://www.edweek.org/leadership/how-schools-are-responding-to-migrant-children/2019/04

Creswell, J. W. (1998). Qualitative inquiry and research design: Choosing among five traditions. Sage Publications, Inc.

Crosnoe, R. \& Turley, R. N. L. (2011). K-12 educational outcomes of immigrant youth. Future Child, 21(1), 129-152.

Education Authority. (2020). Schools of Sanctuary. Retrieved October 1, 2020 from https:/ /www. eani.org.uk/school-management/intercultural-education-service-ies/schools-of-sanctuary\#: :text=The $\% 20$ School $\% 20$ of $\% 20$ Sanctuary $\% 20$ award,where $\% 20$ they $\% 20$ are $\% 20$ fully\%20accepted

Enoksen, E. (2019). Perceived injustice in organizations: reasons for segregation of 1mmigrants. Change Management: An International Journal, 19(1): 1-9. https://doi.org/10.18848/2327-798X/CGP/v19i01/1-9

Eren, Z. (2019). Educational problems of immigrant children and solution proposals according to the opinions of administrators and teachers. Bolu Abant Izzet Baysal University Journal of the Faculty of Education, 19(1), 213-234.

European Commission. (2020). Education and migrants. Retrieved October 1, 2020 from https:/ / ec.europa.eu/education/policies/european-policy-cooperation/education-and-migrants_en

EURYDICE. (2019). Integrating students from migrant backgrounds into schools in Europe: National policies and measures. Eurydice Report. Retrieved October 1, 2020 from https:// eacea.ec.europa.eu/national-policies/eurydice/sites/eurydice/files/integrating_students_from_migrant_backgrounds_into_schools_in_europe_national_policies_and_measures.pdf

Farre, L., Ortega, F. \& Tanaka, R. (2018). Immigration and the public-private school choice. Labour Economics, 51, 184-201. https://doi.org/10.1016/j.labeco.2018.01.001

Groenewald, T. (2004). A Phenomenological Research Design Illustrated. International Journal of Qualitative Methods, 3(1), 1-26. https://doi.org/10.1177/160940690400300104

Guba, E. G., \& Lincoln, Y. S. (1982). Epistemological and methodological bases of naturalistic inquiry. Educational Communication and Technology Journal, 30(4), 233-252. 
Hickey, J., Gagnon, A. J. \& Merry, L. (2010). Partnering with migrant friendly organizations: A case example from a Canadian school of nursing. Nurse Education Today, 30, 67-72. https://doi.org/10.1016/j.nedt.2009.06.001

$\mathrm{Hu}, \mathrm{B} \& \mathrm{Wu}, \mathrm{W}$. (2020). Parental support in education and social integration of migrant children in urban public schools in China. Cities, 106, 1-9. https://doi.org/10.1016/j.cities.2020.102870

Hudelson, P., Dao, M. D., Perneger, T. \& Paillard, S. D. (2014). A “Migrant friendly hospital” 1nitiative in geneva, Switzerland: Evaluation of the effects on staff knowledge and practices. Plos One 9(9), 1-7. https:/ / doi.org/10.1371/journal.pone.0106758

Hummel, D. J. (2015). Immigrant friendly and unfriendly cities: Impacts on the presence of a foreign-born population and city. Journal of International Migration and Integration. https:/ / doi.org/10.1007/s12134-015-0464-7

Jaeger, F. N., Kiss, L., Hossain, M. \& Zimmerman, C. (2013). Migrant-friendly hospitals: a paediatric perspective - improving hospital care for migrant children. BMC Health Services Research 13(1), 389. https:/ / doi.org/10.1186/1472-6963-13-389

Jensen, P. (2015). Immigrants in the classroom and effects on native children. IZA World of Labor,194. https://doi.org/10.15185/izawol.194

Koch, J. M., Gin, L. \& Knutson, D. (2015). Creating safe and welcoming environments for immigrant children and families. APA Changing communities and schools, 12. Retrieved October 1, 2020 from https://www.apa.org/pi/families/resources/newsletter/2015/12

Konings, P. (2017). Protecting immigrant children's right to education. Retrieved October 1, 2020 from https://www.americanbar.org/groups/public_interest/child_law/resources/ child_law_practiceonline/child_law_practice/vol-36/mar-apr-2017/protecting-immigrant-childrens-right-to-education-/

Koski, W. (2019). Advice on keeping 1mmigrant students safe at school. Retrieved October 1, 2020 from https://law.stanford.edu/2019/07/19/advice-on-keeping-immigrant-students-safe-at-school/

Lander, J. (2018). The strengths of immigrant students. Harvard Graduate School of Education. Retrieved October 1, 2020 from https://www.gse.harvard.edu/news/uk/18/04/strengths-immigrant-students

Malik, A. \& Manroop, L. (2017). Recent immigrant newcomers socialization in th workplace roles of organizational socializatio tactics and newcomer strategies. Equality, Diversity and Inclusion: An International Journal, 36(5), 382-400.

Manzoni, C. \& Rolfe, H. (2019). How schools are integratıng new migrant pupils and their families. National Institute of Economic and Social Resarch. Retrieved October 1, 2020 from https://www.niesr.ac.uk/publications/how-schools-are-integrating-new-migrant-pupils-and-their-families 


\section{MİLLî EĞİTiM • Cilt: 50 • Özel Sayı/2021 • Sayı: 1, (1131-1162)}

McCorkle, W. D. (2018). The awareness and attitudes of teachers towards educational restrictions for immigrant students. (Doctoral Dissertation). Clemson University. ProQuest Number: 10843981

McDaniel, E. L., Nooruddin, I. \& Shortle, A. F. (2011). Divine boundaries: how religion shapes citizens' attitudes toward 1mmigrants. American Politics Research 39(1), 205-233. https:/ / doi.org/10.1177/1532673X10371300

Miller, B.B. (2020). Experiences of immigrant students and the challenges of accessing the community college. (Doctoral Dissertation). The Temple University. ProQuest Number: 27834032.

Mitnik, P. A., Finnerty, J. H. \& Vidal, M. (2008). Cities and immigration local policies for immigrant-friendly cities. Cities and Immigration. Madison, WI: Center on Wisconsin Strategy. Retrieved October 1, 2020 from http://www.cows.org/_data/documents/1164.pdf

Nukpezah, J. A. (2017). Creating an immigrant-friendly society: What drives feelings toward immigrants? Journal Of Polcy Practıce, 1-22. https://doi.org/10.1080/15588742.2017.13446 05

OECD. (2015). Helping 1mmigrant students to succeed at school and beyond. Retrieved October 1, 2020 from https://www.oecd.org/education/Helping-immigrant-students-to-succeed-at-school-and-beyond.pdf

Oktik, N. \& Değer, F. (2013). An essay on the role of education in the formation of immigrant identity. Journal of Sociology, 28, 107-123.

Omelchenko, E. A. (2019). Education of international migrants' children: a contribution to the sustainable development? Vestnik RUDN. International Relations, 19(2): 306-316. https:/ / doi.org/10.22363/2313-0660-2019-19-2-306-316

Raol, A. R. (2020). "But what if you just listened to the experience of an immigrant teacher?": learning from immigrant/transnational teachers of color in early childhood teacher education. (Doctoral Dissertation). Teachers College, Columbia University. ProQuest Number: 27997864.

Sanders, P. (1982). Phenomenology: A new way of viewing organizational research. Academy of Management Review, 7(3), 353-360.

Schiff, M. (2008). Immigrant students in public schools: to what extent do school leaders recognize, promote, and utilize their cultural diversity? (Doctoral Dissertation). Southern Connecticut State University. ProQuest LLC.

Schools of Sanctuary. (2020). What is a School of Sanctuary? Retrieved October 1, 2020 from https://schools.cityofsanctuary.org/about

Shepard, E. A. (2016). The emerging "immigrant-friendly" city: how and why cities frame themselves as welcoming places to immigrants. (Published Thesis). Department of Geography College of Arts \& Sciences, University of Vermont. Burlington. ABD.

Solis, L. (2016). Why refugee education is a problem - and six solutions. World Economic Forum. Retrieved October 1, 2020 from https:/ / www.weforum.org/agenda/2016/05/why-refugee-education-is-a-problem-and-six-solutions / 
An Immigrant-Friendly School According to the Views of Students, Teachers and Principals

Stevens, G., Boer, M., Titzmann, P., Cosma, A. \& Walsh S. (2020). Immigration status and bullying victimization: Associations across national and school contexts. Journal of Applied Developmental Psychology, 66, 101075. https://doi.org/10.1016/j.appdev.2019.101075

Tsapenko, I. P. (2015). Social effects of immigration. Herald Of The Russian Academy Of Sciences, 85(5), 443-452. https://doi.org/10.1134/S101933161505010X

Turkish Language Society. (2020). Migration. Retrieved October 1, 2020 from https://sozluk. gov.tr/

Van Maanen, J. \& Schein, E. H. (1979). Toward a theory of organizational socialization. Retrieved October 1, 2020 from https://core.ac.uk/download/pdf/4379594.pdf

Yan, K., Wu, L., Liu, S. \& Jiang, L. (2020). The distinction of elementary education for migrant children in Beijing: a multiple-case study. The Australian Educational Researcher. Springer. https:/ /doi.org/10.1007/s13384-020-00377-w

Yıldırım, A. \& Simsek, H. (2013). Qualitative Research Methods. Seçkin Publishing.

Yıldırım, A. \& Simsek, H. (2016). Qualitative research methods in the social sciences. Seçkin Publishing. 